\section{Carcinoma is a Parasitic Disease.}

Being the Bradshaw Lecture delivered before the Royal Colleg of Strgeons of England.

By HENRY T. BUTLIN, F.R.C.S., D.C.L., Consulting Surgeon to st. Bartholomew's Hospital; Vice-President of the College.

IT is probable that cancer has been during many centuries regarded as a parasitic disease. To the ancients it presented. itself as a loathsome beast, which seized upon the breast, drove its long claws into the surrounding tissues, derived its sustenance by sucklng out the juices of its victim, and never even relaxed its hold in death. In those days it was an animal.

I $i$ is probable that at a later date it presented itself to our forefathers rather as a vegetable, and the terms fungous, fungating, and the like, denoted certain conditions of cancer. The likeness of morbid new growths to some of the large parasitic tumours of plants and trees also tended to encourage the bellef in the parasitic origin of cancer.

The moulds which attack and infiltrate the tissues and organs of certsin insectsand the larva of insects, and gradually replace them, although their form may still be maintained and distinguished, remind us of those cases of cancer in which the walls of hollow organs, such as the stomach, although infiltrated and thickened by the disease, still retain their form as walls.

The resemblance of cancerous masses to the masses formed in specific, tuberculous, and other diseases which we now recognize under the general term, the infective tumoursa resemblance 80 close that it is sometimes impossible to distinguish between cancerous and infective masses-provides another reason for the belief in the parasitic nature of cancer. And the disposition of the secondary growths in the two kinds of disease lends still further colour to the theory.

And there are certain parasitic diseases of fish, of the barbel and the pike especially, in which the tumours are almost entirely made up of myxo-sporidia, and in which the resemblance to malignant disease is so striking that it is almost impossible to believe that they are not canceruus.

It would be easy to multiply reasons, some of them wholly fantastical, some quite sound, for regarding cancer as a parasitic disease, or, at least, as a disease due to the presence or influence of parasites.

Of course, the parasite has been frequently sought for, and, as every one knows, has not infrequently been found. Now, it is vegetable, of the nature of yeast. Now, it is animal, one of the sporozoa. Anon, it is a bacillus or bacterium. And, again, it is a body of uncertain character which is sometimes presented to us under the name of its creator. Scheuerlin, Darier, San Felice, Jackson Clarke, Nils Sjöbring, Sudake. vitch, Ruffer, Plimmer, Pfeiffer, and I know not how many clever and distinguished men, have believed in the existence of a cancer parasite, and have presented it in one form or another to the scientific world; always with the same result down to the discoveries of the last few months. It has been examined. tested, tried and found wanting, until, at length, the Director of our Imperial Cancer Research, in the Scientific Report of this year (I905)', gays: "The parasitic hypothesis has been subjected to severe criticism in practically every textbook of pathology."

It might, therefore, be thought that the parasitic theory of cancer should be buried, never again to be unearthed except as a warning to those who come alter us of the waste of time and energy which may be incurred by a too obstinate adherence to a preconceived idea. Yet, so strong is the feeling in the minds of many surgeons in favour of the parasitic theory, that I confess I experienced a grave sense of disappointment when I found it ruthlessly condemned by our Director, particularly as the first issue of the sclentific reports last year raised the hope that it might be considered from another point of view. ${ }^{2}$

I am afraid it will be regarded as nothing short of audarity that I should, in the face of the almost unanimous opinion of pathologists, once more insist that carcinoma is a parasitic disease, not in the limited sense in which the term appears to have been used of late, as synonymous with infective, but in the larger and wider sense in which it used to be, and should always be, emplosed, to express the fact of one organism living at the expense of another organism, each pursuing its otherwise separate and independent existence. The organism which lives upon the other is the paraslte, and the organism on which it lives is the host, and these terms, which are perfectly well understood, I ehall employ. And I shall limit the discussion to carcinoma, not because there appears to me to be an essential difference between sarcoma and carcinoma in relation to the parasitic theory, but to avoid confusion, and on account of the much greater attention which has been paid to carcinoma experimentally, and because a single lecture is far too small a compass in which to compress a consideration of all and every kind of malignant disease.

Before I go farther I wish to direct attention to some important modifications in the views of cancer pathologists. For many reasons the elements of carcinoma were regarded, until quite recently, and probably are still regarded by many pathologists, as directly derived from the elements of the part in which the carcinoma first appears. It is much more easy to exhibit this in epithelioma than in the other varieties

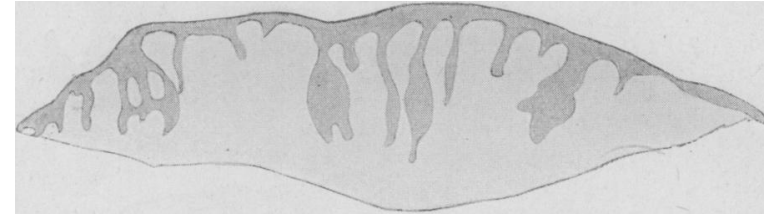

Fig. x.-Transition of normal into abnormal processes of the epidermis. (Butlin, Sarcoma and Carcinoma, 1882, Plate 3.)

of carcinoma, and I show here one of my own drawings, made many years ago, for the purpose of illustrating the transition of the normal into the abnormal processes of carcinoma. It was further believed that, although the growth of carcinoma is chiefly due to the growth and reproduction of its own proper cells, it may also in part be due to transformation of the elements of the normal tissues, similar to the primary transformation out of which the carcinoma had its origin. And there was alwags doubt regarding the origin of the stroma or framework of carcinoma.

A few years ago, I think Rlbbert first maintained, from the examination of much earlier specimens of carcinoma of the skin than had previously been submitted to pathologists, that the microscopic anatomy of continuous sections of these early growths does not support the theory of the derivation of carcinoma from the extension downwards of the normal processes of the epidermis. The very youngest carcinoma of the skin consists of cells which resemble in many respects the cells of the epidermis, and which may lie in contact with the processes of the epldermis, but which cannot be shown to be derived from the cells of the epidermis. On the contrary; the cells of the carcinoma may invade the processes of the epidermis, may change their shape by pressure, and may lead to their destruction, bat the carcinoma cells are neither transformed into normal cells, nor can they be shown to be derived from the normal cells. This view is now held by many pathologists, and is maintained by our Director, Dr. Bashford, and his assistant, Dr. Murray. To illustrate it I have copied drawings and diagrams of Ribbert and Borrmann for carcinoma of the skin, and of Bashford for carcinoma of the tongue.*

The second modification is even more important, and it also is supported by the obseryations of our research: that the growth of carclnoma depends on the growth and reproduction of its own proper celis, and does not depend on transformation of the neighbouring cells into carcinoma cells. Our Director confirms this view from the examination of carcinoma of different varieties in different parts of the body. There is no transformation of the normal cells of the adjacent parts, whether these be squamous or columnar or spheroidal. They may be thrust aside by the carcinoma cells, or undermined, or atrophied, or actually destroyed, but they are not transformed. The growth of the disease is due to the multiplication of its own proper elements.

* In this connexion it is very interesting to study the third plate of Thiersch's at]as, which is intended to show the origin of cancer of the 8kin from the processes of the epidermis. Two of the figures show precise be used for their purpose. But it either had es $3 a$ ped the observat!on of Thiersch or had been differently in'erpreted by him. 
There is a third matter on which our Director has been working and has made authoritative statement: the origin of the stroma or framework of carcinoma. This has frequently been discussed; but our pathologists have watched its development day by day in carcinoma which has been inoculated. They tell us that it is derived from the connective tissue of the part in which the carcinoma grows, and does not depend on transformation of the carcinoma cells. Whether the stroma is formed as a result of "irritation" produced by the presence and progress of the disease; whether it is disposed and arranged in this manner or in that manner in obedience to an influence exercised by the carcinoms cells. as was suggested many years ago by Ballance and Shattock, I do not know.

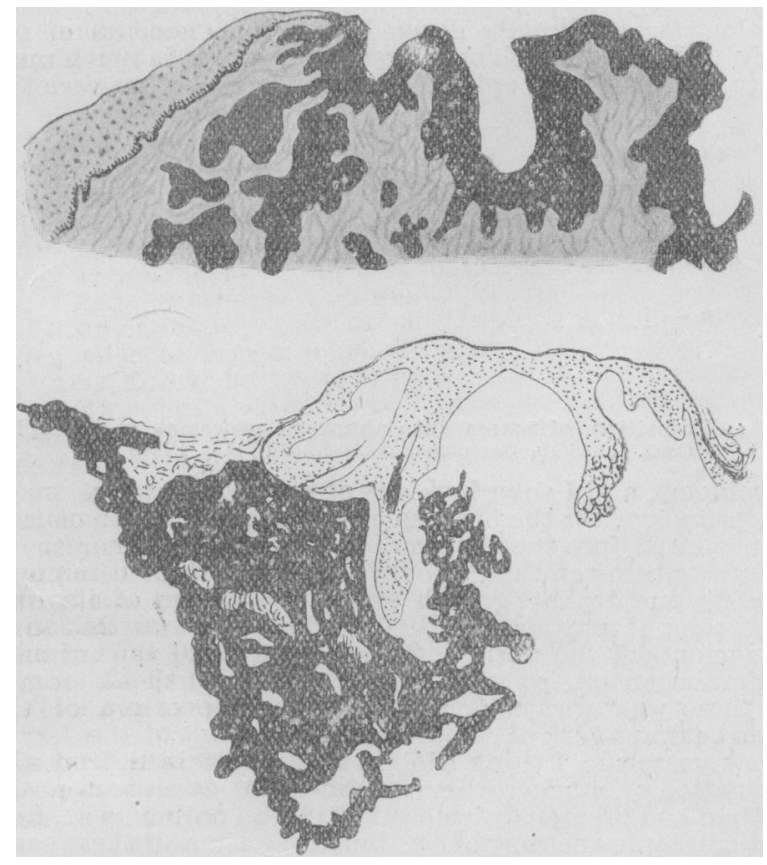

Figs. 2 and 3.-Carcinoma of the skin and adjacent epidermis. (Ribber Geschwulstlehre, 1904. Fig. 469 ; ard Borrman "Zeitschrift fur hitb:jorschung, 1904, Bd. II, p. 86 , Fig. 45 .)

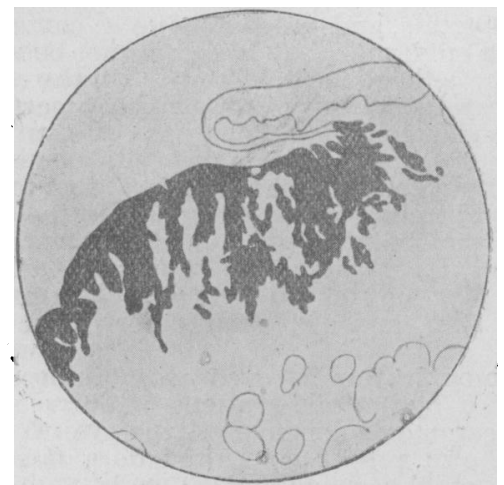

Fig. 4.-Very early epithelioma of the tongue, with adjacent mucous membrane. (Bashford, Scientific Kepuris on the Investigations of the Imperial Cancer Research Fund, No. 2, Igo5, F'ig. 35.)

It suffices for my purpose that modern observation, under the most favourable conditions, shows that there is no transformation of normal cells into carcinoma cells in the course of the growth of the disease, and that the stroma is not developed from the cells of the carcinoma. And, for the present, there is no direct evidence that the cells of the youngest carcinoma are derived from the cells of the part in which it first appears.

On these and other grounds, which I will presently mention I shall maintain that the carcinoma cell is an independent organlsm, like many a protozoon; that it lives a life which is wholly independent and proper to itself; and that it lives as a parasite in the body of the animal which is affected with carcinoma, deriving its nourishment from this host, and doing nothing to repay the host for the sustenance of which it robs him.
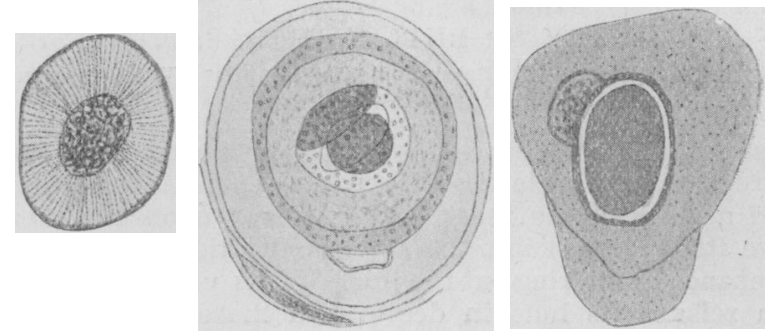

Fig. 5.-Young carcinoma cell, with nucleus and membrane. Fig. 6.-Large carcinoma cell with double membrane and multiple Fig. 7.-Carcinoma cell without aclei. Domergue, Lss Cancers Epitheliaux, 1898, Plate II.)

See what the cell is like. It presents itself to us as a mass of protoplasm, sometimes, but not always, surrounded by a membrane, and containing a nucleus. The nucleus and the body of the cell consist, so far as we have ascertained, of constituents precisely similar to those of which the simplest protozoa are composed. The protoplasm of the cell often contains granules, and is frequently vacuolated. It generally exhibits the same general characters in the same carcinoma, but its shape and size are affected by its surroundings and by the conditions under which its life is passed. Such is its anatomy; it is the anatomy of the simplest forms of animal life.

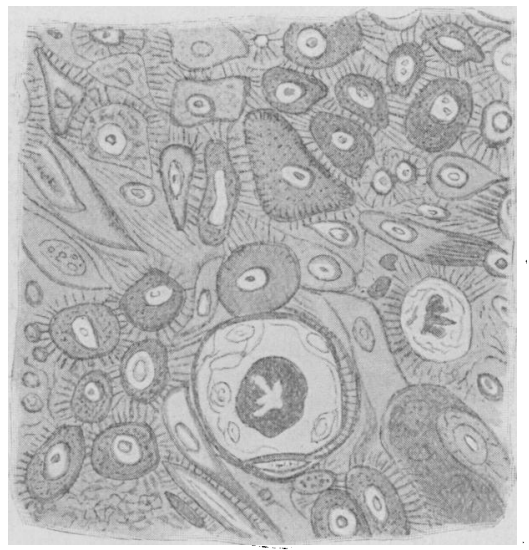

Fig. 8.- Section of squamous carcinoma, showing prickle cells. (From Plate II of Fabre-Dumergue.)

Of its physiology we know less, for it has not yet been possible to study it outside the body of the host. Eixamined on a warm stage, it is said to exhibit a moeboid movement, and to change its shape. The prickle cells which we frequently meet with in squamous-celled carcinoma remind us of the pseudopodial processes of certain of the protozor. We may assume that it ingests, digests, and excretes, and that many of the appearances which the cells present on section are due
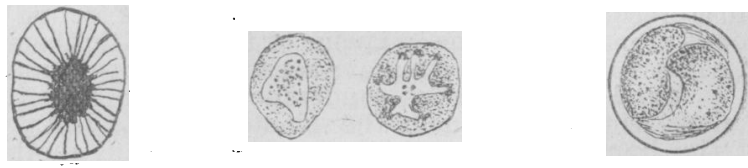

Fig. 9.- Nucleus of calciluba.

Fig, 10-Cells oi Plasmodium malariae.

Fig. Ir.-Colpoda steinii cells. (All trom calkins, The Proto:oa, xgor, Figs. 14,8 , and 17 .)

to these phenomena. There can be no doubt that it may become surrounded by a membrane, that the membrane may become horny, and that the cell is liable to dropsical and degenerative changes. 
Although we have not been able to follow all the phases of reproduction in the carcinoma cell, there is evidence that this takes place by mitosis and by amitosis, and the conjugation of nuclei has been observed not only in sections taken from carcinoma of the lower animals, but in carcinoma from the human subject. Whether this conjugation is concerned with the reproduction of the cells, or whether it is a means by which they renew their vitality, may be doubtful, but it appears to be of vast importance in the lives of the simplest animal forms.

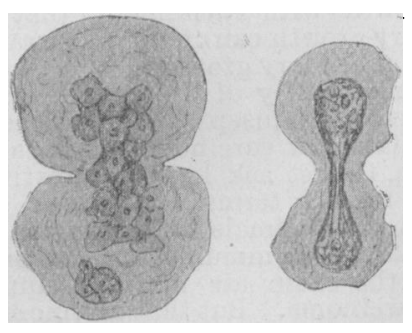

Fig. 12.-Direct division of cell or carcinonau the breast.

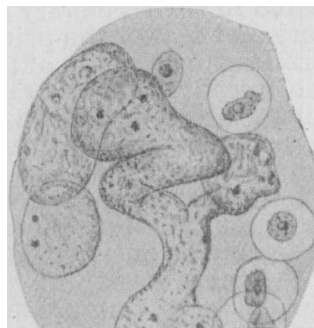

Fig. 13.-Endogenous multiplication or a cell trum carcinoma of the of Fabre-Domergue.)
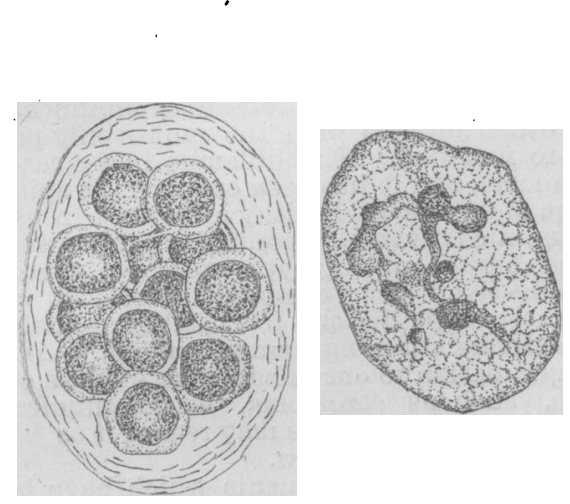

Fig. x4-Actinosphoerium Iisch.

Fig. 15.-Branching nucleus of Ephelota.

Fig. 16.-Division (budding) of Euglypha slveolats. (All from Calkins, Figs. 17, 28, 54, and 23.)

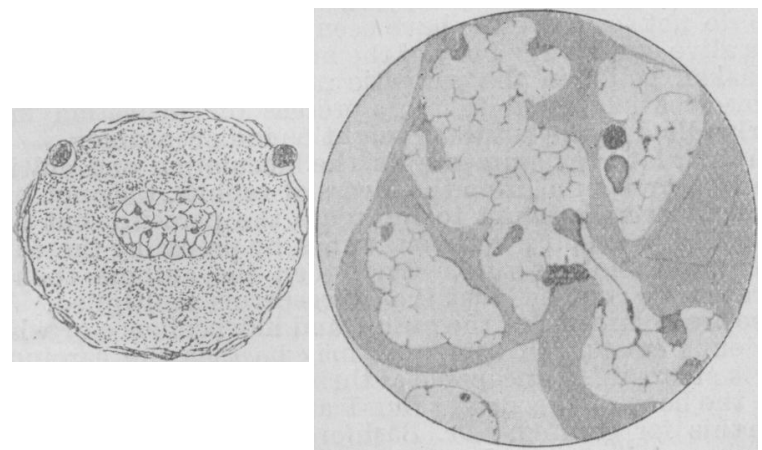

Fig. 17.-Conjugation of nuclei of Actinophrys.

Fig. 18.-Conjugation of nuclei from epithelioma of mouse.? (Bashford, Scientific Reports, No. x, 1904, Fig. 32.)

Whether the cells of carcinoma never die a natural death, and thus fulfil the axiom that " unit masses of living matter are in some measure exempt from natural death," I do not undertake to say, but one thing is sure, that they exhibit a singular tenacity of life, for they have been kept for many days at a temperature of less than $27^{\circ} \mathrm{F}$., or have been placed in sterilized flasks of glass and sent across the sea by post and have in each instance been inoculated with as good result as if they had just been transplanted from one animal to another. There seems, therefore, no reason to doubt that they may live during long periods of time, provided the conditions are sufficiently favourable. Our Director thinks they do not produce or "manufacture" any specific poison which is hurtiul to the tissues of the host; but, on the other hand, they certainly seem to be liable to the attacks of pathogenic organisms in the same way in which the myxo-sporidis of the barbel and the pike are liable to them. ${ }^{15}$

Of course, I cannot claim that the life-history of the carcinoms cell is complete in the sense in which it is complete for many of the protozoa. It would be strange if it were so, for hitherto it has been almost entirely studied as a dead organism, and with preconceived opinlons on its origln and nature.

Let us imagine a tumour wholly composed of such elements as these cells, having no other interest than their own maintenance and the reproduction of the species; tenacious of life, even under very adverse conditions; probably capable of living long periods of time where the conditions are moderately favourable, but not thriving and multiplying unless they are peculiarly favourable, even then usually not developing or multiplying very rapidly. Let us imagine that, in the growth of the tumour and in the destruction which is occasioned by its growth, masses of cells are detached and carried to distant parts of the body, where they sometimes meet with conditions which are favourable to their maintenance and multiplication; or that young cells, or spores of cells, gain access to the interior of the blood vessels and lymph vessels, and are canght up and carried in the circulation until they are arrested in the vessels of distant organs and tissues, where they may, or may not, meet with conditions which are favourable to their maintenance and multiplication.

Let it be understood that they take no part in the maintenance or repair of the body in which they live; that they are not themselves transformed into the normal tissues of the part in which the tumour grows, nor do they transform the cells of the part into their own likeness; and that the only relation between the cells of the part and the cells of the tumour is that the cells of the part are, so to speak, commanded to form a stroma suitable to their support and maintenance. Let us take no heed for the moment of the likeness of the cells of the tumour to the normal cells, and we have all the materials which are needed to explain almost all the phenomena of carcinoma with which we are acquainted:-

The commencement of the disease in the form of a tumour which is scarcely more than a tiny spot or an indolent lump, without pain and without discomfort, which has probably been growing for some time before it was discovered. The increase of the tumour, usually not very rapid, but sometimes more slowly, sometimes more rapidly, as the conditions of life are favourable to the cell, and its vitality is less or greater. The destruction of the tissues of the part in which the tumour grows. The exposure of the tumour when the superficiai structures are destroyed, and the consequent processes of suppuration, ulceration, and sloughing, due to the access of pathogenic organisms to the tumour cells. The long lines of cells, similar to those of the tumour, which are often found beyond the limits of the tumour in the interstices between the muscular fibres. ${ }^{\sigma}$ The occasional blocking of the calibre of lymph vessels and blood vessels by a similar extension along them of the multiplying cells of the tumour, which have gained access to them at some point where the walls are weak or broken. The frequent occurrence of secondary masses in glands, and lungs, and liver, and in other organs and tissues; each mass composed of cells so like in shape and character to those of which the primary tumour is made up, that there is no doubt of their source, so like that the nature of the primary disease may often be determined without fail from an examination of the secondary growths. The occasional occurrence of tumours in the lungs due to the detachment of small masses of cells which are carried in the air stream, and deposited in the smallest bronchi, and which are composed of cells precisely similar to those of the primary disease.-All these phenomena are at once clear to us.

We can understand not only why these secondary growths occur, but, in a manner, why they fail to occur. The conditions are not favourable to the activity and multiplication of the cell. And, bearing in mind the tenacity of life with which the cell is endowed, we may assume that although the conditions are not for the moment favourable to the active life of the cell, they are yet not so unfavcurable as to destroy its 
and that it may lie dormant in the parts to which it has gained access du cing long periods of time, until the conditions become more favourable, when it resumes its activity, and multiplies as if it still formed part of the orjginal tumour. Thus we can understand why the occurrence of secondary tumours in the glands and other organs is sometimes so long deferred. We can appreciate something of the conditions on which depend very late vccurrences of carcinoma in glands and other organs which take place years after the successful removal of the primary disease, and which have always been a puzzle to ug. During those long years the cells have probably lain dormant, not dead but sleeping, until what we are pleased tú csll "some chance" awakens them from their torpor, puts new life into them, and enables them to prosper and multiply exceedingly. More than once I have seen carcinoma thas lighted up in glands long after it ought naturally to have occurred, and just when we were beginning to hope that all danger was at an end once by exposure of the side of the neck to a cold draugh during several hours, and more than once by an attack of in flammation of a salivary gland, within or in the immediate neighbourhood of which the lymphatic glands were placed.

We can understand why our operations fail and why they succeed. The surrounding tlssues are already widely intiltrated by the parasite in the one case, and we have not cut beyond it ; or it has already gained access to some gland or distant organ. In the other case, it is less vigorous and active, and having gained but a poor foothold on the tissues of the host, has been easily and effectively removed. The action of destructive agents is jast as intelligible: it is a question of complete destruction.

As certain tissues and organs of the host receive the wanderIng cells coldly, as if they would only harbour them and give them shelter, so we may assume that there are tissues and organs of the host which are not suited to the support of the cell, and which never can be rendered suitable ; and that there are other tissues and organs which are only suitable at certain times and under certain conditions. And, as these may become more suitable at one time and the cells may not merely find refage in them but may even grow and multiply so, at another time, circumstances mas render them less suited to the life of the carcinoma cell, and we can thus comprehend those rare instances in which the carcinoma undergoes spontaneous cure, either without or after operation. And in the same way we can understand the rise and fall in the tide of carcinoma, how the tumours are at one time smaller, and again larger and more active; how the patient may, indeed, seem to have been cured, but the cure has been delusive, due to lowered vitality of the parasite or to raised resistance of the tissues of the host. And to this greater resistance we must attribute the happy result of those treatments, such as removal of the ovaries, or the administration of such remedies as thyroid extract, which have occasionally achieved a success which has raised the wildest hopes in the minds of patients and their medical men.

With regard to the general condition of 'the host at the time of the first appearance of carcinoma, it is a matter of common knowledge that many parasites, particularly vegetable, obtain access to the body of the host when its strength is Impaired; and it is equally a matter of common knowledge to our profession that many of the patients who suffer from carcinoma "are, for their age, in a full average of general good health." ${ }^{\circ}$ But it must not be forgotten that, although the health of the whole body may be or seem to be unimpaired, the health of the part attacked is more frequently impaired than not. Of the greater liability of one sex than the other to carcinoma, it may be safely held that this is largely a question of the greater or less liability of particular organs and tissues, and of their condition at the time of the attack. And again, of inheritance, it may be said that it is the inheritance, not of the disease, but of organs and tissues which are peculiarly vulnerable to the disease, and that the nature of the inheritance is the same as that of many persons to the attack of the tubercle bacillus.

Of the influence of dwelling and soil and climate it is too soon to speak. They stand for the present discredited, and the age incidence is in the ascendant. But $I$ am not yet disposed to rate them as of no consequence in the etiology of carcinoma.

I might continue this part of the subject to occupy the remainder of the lecture, but there are certain problems which command attention. If the carcinoma cell is an independent organism, living as a parasite, it ought to satisfy some, at east, of the following requirements: It should present the same or similar characters in every part of the host in which it occurs; it should be transmissible from one part to another of the same host ; it should be transmissible from one host to another host under certain conditions; and it should be capable of living outside the body of the host, as some similar parasites are able not only to live but to thrive and multiply outside the body of their host.

The first and second of these conditions are fulfilled so regularly and so frequently that every student knows that carcinoma is conveyed through the medium of the blood and lymph, and that the characters of the primary disease are repeated in the secondary growths with such fidelity that the variety and seat of the primary growth can often be accurately determined by a study of the secondary growths.

The question of the transmissibility of the parasite from one host to another host is naturally inseparably involved in the question of the infective nature of carcinoma. In dealing with this part of the question, I must ask leave to substitute the term "communicable" for the terms "infective" and "contagious." Mere contact with animals suffering from the disease may be quite insufficient to communicate carcinoma ; and the mere breathing of the same air may be equally inefficient to communicate carcinoma. But that carcinoma is a communicable disease there can remain no possible doubt. Whether Morau, as Fabre-Domergue asserts, ${ }^{7}$ was the first person to successfully inoculate mice with cancer some tifteen years ago, or whether priority rests elsewhere, there is not the least doubt now that carcinoma of mice is successfully inoculated in mice by many pathologists in many countries. The experiment has been repeated with such a large percentage of success that no one any longer doubts it. If, therefore, the carcinoma of the mouse is identical in nature with carcinoma in the vertebrate animals generally, carcinoma is a communicable disease ; and all failures to communicate it by inoculation in other animals than the mouse only prove that it is difficult to inoculate. The difficulty in the case of mice has been overcome, and it has been overcome in spite of the fact that large numbers of healthy mice kept in cages with carcinomatous mice have not contracted the disease. This circumstance has been employed to prove that the disease is not "infective" or "communicable." It only proves that it is exceedingly difficult for healthy animals to contract it from animals suffering from carcinoms. And it is a matter of congratulation to our unhappy race that a communicable disease, such as carcinoma, is communicated spontaneously so very rarely that we may regard it as " not catching" from a popular point of view.

Hitherto, I believe that all experiments which have been made with the object of cultivating the carcinoma cell outside the body of the host have resulted in failure, and this has. been regarded as strong evidence against the parasitic theory. Even if it be admitted, it is not a serious obstacle to the acceptance of the theory, for there are other parasitic organisms which are believed to be unable to exist outside the body of the host. But I am sure the last word has not been spoken on this part of the subject. Ballance and Shattock, ${ }^{8}$ who do not seem even to have been successiul in keeping the cells alive outside the body of the host, still maintained their unshaken belief in the parasitic nature of the disease; and themselves suggested that "a process of cultivation more. nearly allied to the natural " might be indispensable.

In their later experiments on the inoculation and cultivation of psorosperms from the livers of rabbits, they not only failed in every attempt to inoculate the parasite, but only succeeded in keeping it alive in tabes by preparing the tubes with rabbit-blood serum. Even then the authors thought there was no evidence that the psorosperms multiplied. Yet these are organisms of the nature and independence of which no doubt exists. Of course, it may be that the carcinoma cell is an organism incapable of thriving and multiplying outside the body of the host. But I am not at all disposed to take this for granted. Dr. Bashford quite confirms the experience of Professor Jensen ${ }^{9}$ on the vitality of the cells of carcinoma. Jensen made successful inoculations from tumours which had been preserved for eighteen days in ice at a temperature of $0.3 \mathrm{C}$., while the incubator at body-heat seemed to agree with the cells so ill that less than forty-eight hours of it sufficed to render the results of inoculation negative. Then Professor Jensen forwarded by post, under sterile precaution, portions of tumour from Copenhagen and, five days later, Dr. Bashford inoculated it with such success that more than 25 per cent. of the inoculations were successful. After this, it is clear it would be premstare to express the opinion that the cells of carcinoma belong to the class of 
parasitic organisms which cannot be induced to thrive and multiply outside the body of the host. That they can llve apart from the host is clear. Whether they can thrive there is yet to be discovered.

Thus the carcinoma cell satisfies what is required of it so far that it presents the same or similar characters in every part of the body of the host in which it occurs. It is transmissible from one part to another of the same host. It is transmissible under certain conditions from one host to another host. It will live outside the body of the host for many days; and at the end of many days, if it be placed in favourable conditions, it will thrive and multiply as if it had never left the body of the host.

I must confess, seeing how well this theory explains almost all the phenomena of carcinoma. and how much evidence is already present in proof of it, I am surprised that it has scarcely been maintained before. Hauser ${ }^{10}$ is the only pathologist, so far as I am aware, who has propounded it in his attempt to show that the cells of carcinoma are a new race of cells.

In truth, everybody who has worked at cancer has been far more engaged in attempting to discover the origin of the cell than to determine what it is. Our minds have been possessed by the conception of the cell of carcinoma as a normal epithelial cell which has escaped from the bondage of the laws which confine such cells, and has, so to speak, run wild, obeying no laws and performing no dutles. Pathologists have been wondering what has driven it to such evil courses. Some have explained it by assuming that every epithelial cell is capable of acting in like manner if certain restraints, local or general, are lowered or removed. Others suggest that the unnatural activity of the cell of carcinoma is due to irritation of the cell itself. Others that the ill-mannered and unmanageable cell is derived, not from the normal epithelium but from cells which were intended to become epithelial, but which have remained embryonic and in a dormant condition for as many as fity years or more. And from Professor Farmer ${ }^{11}$ and his colleagues we have received information of anotber kind which may help us to the discovery of the genesis of carcinoma in the future.

Although for the present I am much more concerned in determining the nature of carcinoma than its origin, and the object of my lecture is to persuade blologists and pathologists to help us to solve the problem, which I do not think so very difficult; and although I might fairly claim that the consideration of its genesis is no part of my duty, it would be absurd that I should close my eyes to the difficulties of the problem of its origin, if the carcinoma cell is admitted to be an independent organism-a parasite within the body of the host. I suppose we must then assume that the parasite is introduced into the body from without, after the manner of parasites generally; or that it is formed, in some unknown manner, within the body of the host.

In favour of the former view many reasons can be urged. Carcinoma first appears in a very large number of casès either on or just beneath the external or internal surface of the body. Or, if it appears at some distance beneath the surface, it frequently attacks parts to which there is free access from the surface-take the breast as an example. In many instances the part which is attacked is lowered in vitality ${ }^{*}$ it is a sick part: it has been prepared for the entrance of the parasite by injury, or long-continued inflammation, or by degeneration. We are familiar with this preparation in parts which are frequently and readily examined, such as the lower lip and tongue. And we know, or think we know, that the first appearance of carcinoma in these parts is preceded by an actual wound or sore, through which the parasite may have gained an entrance. And in similar parts of the body which are not so readily examined, such as the larynx, the oesophagus, the intestinal canal, we have the right to assume that the occurrence of the disease is similarly preceded by injury, or long-continued inflammation or degeneration. The youngest carcinomata which have been studied by microscopists appear to be separate and distinct from the tissues of the part in which they occur; and from this separate and distinct mass of cells the extension and dissemination of the disease are traced in so many instances that we cannot doubt that the conditions are the eame for all. The natural or spontaneous occurrence of carcinoma accords in its characters and course with the course and characters of carcinoma which has been inoculated; and the metastases of carcinoma in the body of the host in which it has developed epontaneously are regarded by pathologists, quite justly, as each and every one successful inoculations of the disease wherever they occur. Cases of auto-inoculation and reputed cases of contagion of carcinoma which have been placed on record and which are admitted by many pathologists, but which are for the moment discredited by the pathologists of our own research, point to the same conclusion.

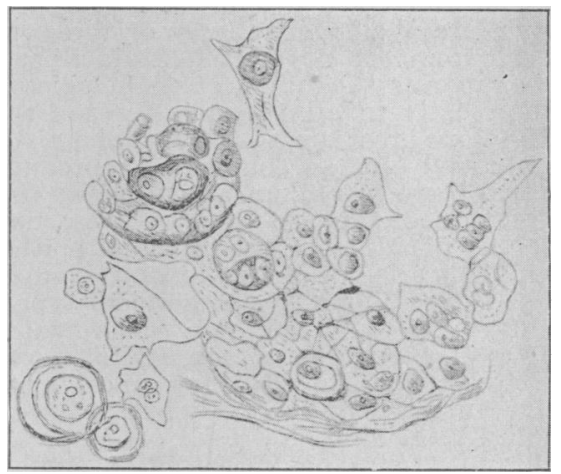

Fig. x.-Metastatic squamous carcinoma of lung. (P.th. Trans.. vol. xxil, Plate III.)

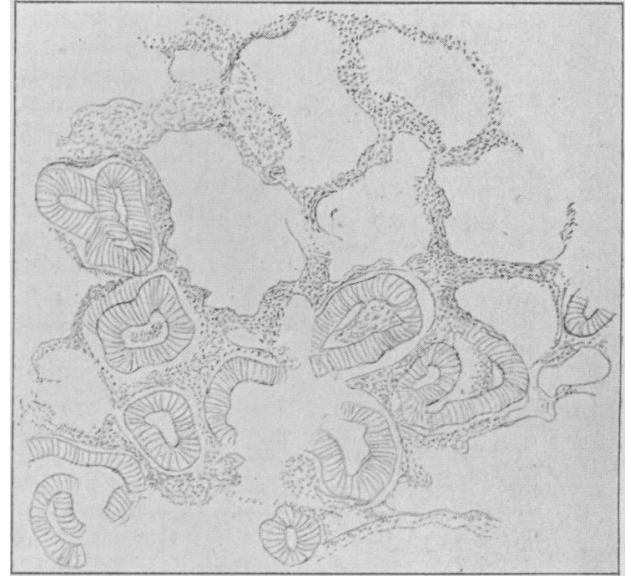

Fig. 20.-Metastatic columnar curcinoma of lung. (Path. Trans. Vol. xxv, Plate VI.)

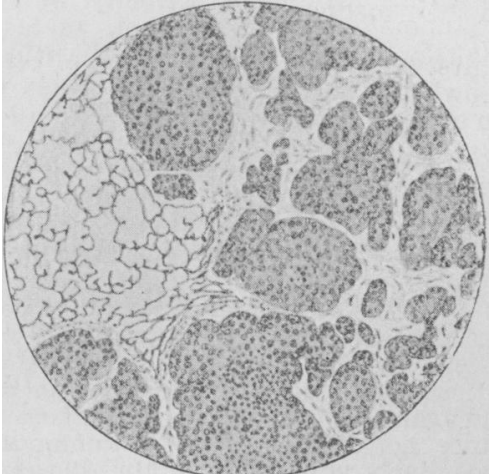

Fig. 2x.-Metastasis of mouse-carcinoma in lung to show the demarcation between the carcinoma and the normal tissues. (Bashford, Scientific Reports, No. 2, Plate XI.)

The more frequent occurrence of carcinoma in particalar houses and in particular districts suggests that the parasite may exist ontside the body of the host in those houses and in those districts; and although many of the cases of cancer houses and cancer districts will not bear close investigation, we are not yet in a position to regard them all as worthless. Indeed there is so much to be said in favour of the entrance of the parasite from without, and the theory is 20 inviting and 
wculd render the further study of the disease so much more simple, that 1 set down with reluctance the evidence against it ; but this is so important and of such a character that it is impossible to pass it by.

First, the characters of the carcinoma cell, the parasite These conform so closely to the characters of the epithelium of the part in which the carcinoma first appears that, for some thirty years, Waldeyer's theory of the descent of the carcinoma cell from the normal epithelium has held almost undisputed sway over the minds of pathologists. The same type of cell prevails in all the metastases of the same carcinoma. The three great types-the squamous, the columnar, and the spheroidal-are so constantly reproduced in their metastases that there is seldom any difficulty in recognizing them. The squamous type, so far as we know, never arises in or in the vicinity of columnar or spheroidal epithelium. The columnar type only arises in close contact w! th tubes lined with columnar epithelium; and the spheroidal type arises only close to acini which are lined with spheroidal epithelium The constancy of this phenomenon is not questioned; the difficulty is to explain it. We may corceive that a single parasite gains entrance to the body from without, comes in close contact with the epithelial cells of the part in which it settles, and is so impressionable that it is moulded into the shape and develops the characters of the normal epithelium. Even if the portsite were crossed with the normal epithelium, it would be difficult to understand why the resulting cells should be so strongly influenced by the mere breeding-in of the two kinds of cell-the parasite and the normal cell. And it is still more difficult to understand why the influence should be transmitted from generation to generation of the resulting cells, so that the cells of every metsstasis present the general cbaracters of the epithelial cell. Again, we may conceive the idea of several parasites, one, for instance, for each of the three great types of epithelial cell-a squamous paraaite, a columnar parasite, and a spheroidal parasite. But it would, even then, be necessary to admit that each of the three parasites will only thrive and multiply when it is introduced into the body in, or in the near neighbourhood of the epithelium which it resembles; or when, by chance, it finds its way there. The proposal is so improbable that we reject it as soon as uttered.

Quite apart from the mere anatomical characters of the three types of cell, and quite apart from the differences in malignancy of carcinomata which depend on the anatomical features and relations of the parts in which the tumours grow, there are reasons for suspecting that the cells themselves vary in the powers they possess. It is notorious that squamous carcinomate chiefly affect the tissues in the immediate neighbourhood of the part in which they grow and the associated lymphatic glands, and that they are rarely disseminated in other parts of the body. It is equally notorious that spheroidal carcinomata form their metastases in the glands, the lungs, the liver. the bones, and other organs and tissues. And it is perfectly well known that columnar carcinomata also form their metastases in the glands, the lungs, and liver. These peculiarities can only be in part attributed to the relation of the parts in which the three varieties of carcinoma primarily occar to the parts in which their metastases are found. And we can only assume that the columnar and spheroldal cells are hardier than the squamous cells, and that they find in many parts of the body of the host conditions which are favourable to their development; while the squamous cells are more dainty, or less hardy, and require more favourable conditions generally, and that these conditions are usually only found in certain parte. This is sometimes singularly illustrated in cases in which two.varieties of carcinoma occur gimultaneously in the same individual. Recently an old gentleman in whom I took great interest died after many months of suffering from carcinoma of the larynx and carcinoma of the rectum. The symptoms of the carcinoma of the larynx were present long before the symptoms of the carcinoma of the rectum, but I will not, on that account, undertake to say that the carcinoma of the larynx preceded, in point of time, the carcinoma of the rectum. The postmortem examination discovered that a large part of the larynx had been destroyed by the disease, and the variety of carcinoms was squamous. There was in the rectum an ulcerated columnar carcinoma which had occluded the lumen of the bowel. There were some cancerous glands in the neck, and these contained : quamous carcinoma; and there were a few small metastases of ctrcinoma in the lung. Now, the carcincma of the larg $n x$ : $h$ iving be' $n$ ulet rated for geveral $m \mathbf{n}$ 'hs and lying right over the entrance to the air passages, might have been expected to be the father of the tumours in the lung; while the carcinoma of the rectum being far distant from the lung, and having no other access to it than the medium of the blood, which was common to both carcinomata, could scarcely have been suspected as the more likely parent. Yet it was so, for the characters of the tumours of the lung were those of columnar carcinoma. Where two varieties of carcinoma come in contact, the one is said to invade the other, and the stronger remains in possession of the field $;^{22}$ but I do not know whether the spheroidal and columnar carcinomata under these circumstances always prevail over the squamous carcinomata.

Secondly, there is the difficulty of the structure of carcinoma, the arrangement and disposition of the parasitic cells, and the stroma or framework in which they are disposed and arranged. It has been already stated that the stroma, so far as the latest researches can decide, is derived from the connective tissue of the part in which the tumour grows. It may be said to hold a subordinate position in the anatomy of the disease. If the formation of the stroma is attributed to the irritation produced by the presence of the carcinoma cells, we should expect that it would be very similar for each of the three types of carcinoma tumour. But this is not the case. The stroma of each of the three types is peculiar to that type, within certain limits, and is not common to all three. Tnis is particularly well shown in columnar carcinoma, in which the cells are disposed and arranged in follicles similar to normal follicles lined with columnar epithelium, but rarely so orderly and regular. If the formation of the stroma is attributed to a kind of influence or command exerted on the connective-tissue elements by the carcinoma cells, like that which the epithelial cells appear to exercise over the connective-tissue elements in the development of the body, it is still more difficult to conceive that parasitic cells entering the body from without should acquire such a specific influence over the connective-tissue elements of the part in which they settle.

Thirdly, there is what is termed the "age incidence" of carcinoma. And I speak particularly of carcinoma here because I still hold to the opinion that the age-incidence of arcoma and carcinoma is essentially different. But for carcinoma there is no doubt; it occurs spontaneously in individuals, for the most part beyond the period of middle life. And the longer men and women live the more likely are they, in comparison with the total number of persons living at that age, to suffer from carcinoma. In other words, the liability to the first attack of carcinoma increases as age advances. The Imperial Cancer Research has taught us that this law is probably as true for animals as it is for man. And our Director suggests that it is equally true for organs. But, however that may be, we have to face the problem of the occurrence of carcinoma in relation to age. Why are middleaged and old people so much more liable to carcinoma than young people, so much more so that young people are generally regarded as almost exempt from carcinoma? For many years past the question bas been answered on the assumption of the descent of the carcinoma cell from the normal epithelium. And the answer has been that this descent cannot take place unless the tissues are degenerated, and that this degeneration is the result of advancing age. We might still accept the necessity of degeneration of the tissues, and assume that a parasite of the nature of the carcinoma cell cannot enter the body and obtain a foothold in it unless the tissues are degenerated. There is nothing unreasonable in the supposition. But inoculation experiments on mice have shown that, although mouse carcinoma occurs spontaneously only, so far as is known, in aged mice, yet inoculation of the disease is as successiul in young mice as it is in old mice. So that it would seem that the tissues of the young and healthy are quite suited to the maintenance and prosperity of the parasitic cells, but that they are not able to produce them.

It must be admitted that these three features of carcinoma, the age-incidence, make it difficult to conceive the idea of a parasite introduced into the body from without. And they do strongly suggest that the parasite is actually formed or developed within the body of the host, and that it is in some manner derived from the elements of the host. ${ }^{13}$ Hauser has no doubt that his new race of cells is derived from the elements of the host, and appears to find no difficulty in the hypothesis. I confess it is to me an astounding proposition ; for, set forth in plain terms, it is none other than the origin of nes species of the lorest forms of animal- of protozos. The 
mode of origin which is suggested is so different from that we have been accustomed to accept for the last five-and-twenty years, that I scarcely dare to set it down in words. That there will be much discussion and dispute over it I cannot doubt for $I$ am quite confident that time and research will confirm the view I have expressed to-day of the nature of the carcinoma cell. And, as I am anxious that it should be confirmed as speedily as possible, I will indicate the weak links in the chain of evidence, and the means by which they may be strengthened.

We want to complete, if possible, the life history of the carcinoma cell outside the body of the host; and, with this end in view, repeated attempts should be made to induce the parasite to thrive and multiply under artificial conditions, which will permit the study of every phase of its existence. We have learned that it can live; we have now to learn whether it can thrive outside the body of the host.

We need incessantly repeated attempts, under all conceivable conditions, to inoculate the carcinoma cells in other animals than the mouse. The Imperial Cancer Research is occupied with these experiments at the present time-thus far without success. I would suggest that the cultivation and inoculation experiments are far more likely to be successful if they are preceded by series of experiments of the kind practised years ago by Ballance and Shattock ${ }^{14}$ on the psoroperms of rabbits. The failure of their attempts to cultivate the parasite and to inoculate the rabbit with psorosperms taken from rabbits clearly shows that the culcivation and inoculation of parasitic protozoa is not by any means so simple a matter as it might be deemed to be, and that the laws and methods of these cultivations and inoculations must be studied and practised again and again under various conditions before the lesson can be learned and successfully applied. In the prosecution of this study lies the clue to the inoculation of other animals besides the mouse.

Finally, we want the most careful and detailed study of cases of reputed contact cancers occurring in the same individual and from one individual to another. This is the only research for which I am competent, and in which I may hope to take a part. Our Director has pointed out to me that, in many of the cases in which one individual is reputed to have caught cancer from another, the disease is not the same in the two individuals. Not only is it not the same variety of carcinoma; it has even been sarcoma in the one and carcinoma in the other. Of course, such cases cannot at the present moment be accepted as cases of contagion. But all the reputed cases of contagion should not be condemned because many of them appear to be worthless. Each individual case must be investigated on its own merits; and I have a very strong impression that some cases of true contagion, if only a very few, will be discovered. I would not yet cast aside the cases which appear to have no value because the disease is not of the same variety in the giver and the receiver. They should be carefully recorded by competent observers, in the hope that even they may throw some light on the problems which we have to solve. I am sure there is no circumstance so small that it should be lightly passed over in this investigation; and, on the other hand, that there is no obstacle so large that it should not be boldly faced and treated without prejudice.

\section{No'TES AND REFERENCES.}

1 Bashiord.-Scientific Keports, Imperial Cancer Research Fund, No. 2 1905, p 81. 2 Bashtord, Scientific Reports, No. r. p. 34, and note. 3 Path. Trans., vol. Xxxviii. 4 Thomson, Outlines of Zoology, 1899. ${ }^{5}$ Mr. Lenthal Cheatie has kindly drawn my attention to the spread of carcinoma of the apparent limit of the tumour, and I have found his observation amply confirmed in some of my own specimens. is Pagt, Clinical Lcctures and Essays, 1879, p. 13. T Fabre-Domergue, Les Cancers Épitheliaux, 1893. 8 Loc. cit., p. 434. 9 Sclentific Reports, Imperial Cancer Kesearch, No. x, p. I4 10 Ziegler's Beiträge zur Path. Anat., 33, S. x, 1903 , Giebt es eine primare zu Geschwulstbildung führende Epitnelerkrankung? 11 Proc. Roy. Soc vol. Ixxii. 12 Sclentific Reports, Imperial Cancer Research, No. I, p. 34, note. ${ }^{13}$ Loc. cit. 14 Path. Trans, vol. Xl11, p. $377, \mathbf{1 8 9 1 .}{ }^{15}$ Pfeiffer, Cnter suchungen iiber den Krels, Jena, 1893.

Medicad Magistrate.-Dr. J. Selwgn Cowley of Upton-onSevern has been appointed to the commission of the peace for the county of Worcester.

Dr. W. G. Stevens, Medical Officer of Health for the Burgh of Renfrew, has had the happy idea of issuing an illustrated health almanac for hanging on the wall; surrounding advice as to the prevention of consumption, advice which if carried out would go far towards the prevention of other diseases also, are pictures of old and new public buildings in Renfrew, and on the back is a diagram of the Hincks Bird ventilating window arrangement. The almanac is called the "Public Health Circular No. 1."

\section{OBSERVATIONS ON THE HEREDITY OF INSANITY.*}

Br A. R. URQUHART, M.D., F.R.C.P.E.,

Physician Superintendent, James Murray's Royal Asylum, Perth.

Is addressing you from this honourable position I bear in mind, first of all, that we meet here for no exclusive or local purpose, but as members of a great Association, representative of medicine and surgery in the widest sense. Last week many of us were engaged in the work of an Association limited in numbers, and specialized in intention; this week the hospitality of Leicester, to our common advantage, affords us opportunity of coming into contact with those who are less intimately interested in our department of medical science. It is the advantage of a wider: horizon, and a freer air. No doubt it will be generally recognized that the main questions which we, as psychiatrists, propose for discussion on this occasion are of vital interest to our profession and to our country. Thus, we are to consider the heredity of insanity, occupation and environment as causative factors of insanity, and prognosis in mental disorders. These are subjects of urgent importance, and if we can elucidate them, and promote their further investigation, we may hope that general principles will be evolved, and will be applied to the advantage of the common weal. I regretfully admit that the guidance of the profession in the political sphere is very frequently regarded with suspicion, and that our advice often talls on deaf ears. There seems to be a lingering objection to adopt measures urged by doctors, fortunate above all in their education and training, seeing clearly that amendment of our civilization is now necessary to avert national calamity. I still more recretfully admit that there are doctors who from time to time offer panaceas which can only be rejected with derision.

What we as a nation require is an intelligent understanding of the methods of Nature and an adjustment of national conditions to these methods in accordance with the circumstances of the day. It is my unhesitating belief that the medical profession will do its part in this regenerative work by the attainment and diffusion of exact knowledge culminating as principles of action.

We have lately discussed heredity in the light of recent researches in biology, and it is not my intention to enter upon a consideration of the results. Indeed, a full critical account of the observations now personally recorded would pass beyond all limits of time and patience. Statistics are more appropriate in cold print than in spoken words. I know that there is a certain impatience of the mere counting of noses, and that the newer school of psychiatry largely asseverates that statistics are unfruitful. I hope. therefore, to avoid, in as far as possible, an intolerable recital of figures and percentages, which, of course, must be the groundwork of this kind of study.

Une feels on rising from a perusal of these depressing records that there is an intolerable deal of madness in the country. When an old friend of mine made polite inquiries of Lord Beaconsfield, "I hope you are quite well," he got answer, "Is there anybody quite well ?" In the records of a special hospital it is in the nature of things that the special disease treated should be prominent, not only in the wards, but in the homes of the patients. Thus, in considering the heredity of insanity, I believe that the lop-sided results are comparatively useless. Professor Karl Pearson suggests that insane inheritance will be found to occur in nearly the same proportion as the inheritance of physical characteristics. What we really require is an investigation into the heredity of diseases, altogether apart from the experience of special hospitals. To that I shall return in the hope of gaining your support for my concluding proposal.

I need not say much about the work which has been done in the past in this particular category. The statistics of insanity were considered under favourable circumstances by Thurmen at the York Retreat (1840), and I hope that the more modern experience of the medical staff there will yet find expression.

Of the later inquiries into insane heredity in this country I might mention three of definite interest. Dr. H. Grainger Stewart, too early lost to our speciality, reported upon gor cases, 49 per cent. having hereditary predisposition to insanity or eccentricity. His careful study was prefaced by references to

* Presidential address to the Section of Psychological Medisine, Annual Meeting held at Leicester, 1905 . 